\title{
Popularising Bill of Exchange As Poverty Alleviation Instrument among Market Women in Ijebu North Local Government Area, Ogun State, Nigeria.
}

\author{
${ }^{1}$ Faderera Oluwatoyin Ashogbon, ${ }^{2}$ Kenny Adedapo Soyemi, ${ }^{3}$ Oluwatoyin \\ Olubunkola Olusola \\ ${ }^{I}$ Department of Business Management Tai Solarin University of Education, Ijagun. \\ ${ }^{2}$ Department of Accounting, Banking \& Finance Olabisi Onabanjo University, Ago Iwoye. \\ ${ }^{3}$ Department of Business Management Tai Solarin University of Education, Ijagun.
}

\begin{abstract}
The purpose of this paper is to provide insights into the nature of the bills of exchange as a source of finance for commercial transactions among market women in Nigeria. It examines the use of the instrument both as a means of remittance and credit. It also gives a comprehensive view of the problems and prospects of the instrument. The first part gives the definition of bills of exchange, while the second part explains the usage of the instrument with the accounting entries. The third part looked at the rate of use and adoption of the instrument among these market women. A random sample of 100 respondents was drawn from market women in Ijebu-North Local government Area of Ogun State. Descriptive statistics was used in presenting the data collected. Results of analysis showed that the use and adoption of bill of exchange is not popular among Nigerian market women.
\end{abstract}

Keywords: Bills of Exchange, drawer, drawee, payee, Ogun state

\section{Introduction}

The financial system is part of the institutional structure that facilitates economic transactions. Specifically, the financial system facilitates lending, payments and trade in risk. While lending often steals the limelight, the role of the financial system in facilitating payments and trade in risk is no less essential. As commerce expanded, the pressing need for adequate means of payment prompted a great deal of financial innovation-in particular, the emergence of the deposit bank and the bill of exchange. The deposit banks provide means of payment-the transfer of deposits-that minimized the need to use actual cash. The bill of exchange, the subject of the current paper, provided a means of remittance-of transferring funds from one place to anotherwithout having to ship specie or bullion. It is also an instrument of credit, the basis on which merchant banks built an efficient international system of commercial credit. While the bill of exchange satisfied the need for short-term finance, the growing need for long-term finance was met by a developing capital market. This paper tries to find out the use and adoption of the bill of exchange among Nigerian market women.

\section{Meaning of Bill Of Exchange}

A bill of exchange is a written order from one person to another signed by the person giving it, requiring the person to whom it is addressed to pay on demand or at some fixed future date, a certain sum of money, to either the person identified as payee or to a person presenting the bill of exchange. In other words, a bill of exchange is a written order directing that a specified sum of money be paid to a specified person.

Bills of exchange are similar to cheques and promissory notes. They can be drawn by individuals or banks and are generally transferable by endorsements. The difference between a promissory note and a bill of exchange is that this product is transferable and can bind one party to pay a third party that was not involved in its creation.

\section{Origin of bill of exchange}

The bill of exchange originated as a method of settling account in international trades. Arab Merchants used a similar instrument as early as the $8^{\text {th }}$ Century $\mathrm{AD}$, and the bill in its present form attained wide use during the $13^{\text {th }}$ Century among the Lombards of Northern Italy, who carried on considerable foreign commerce. Because merchants (the buyers) usually retained their assets in banks in a number of trading cities, a shipper of goods (the seller) could obtain immediate payment from a banker by presenting a bill of exchange signed by the buyer (who, in so doing, had accepted liability for payment when due).

The banker would purchase the bill at a discount from its full amount because payment was due at a future date. The purchasing merchant's account would be debited when the bill becomes due. Bills could also 
be drawn directly on the banks themselves. After the seller received his payment, the bill of exchange continued to function as a credit instrument until its maturity, independent of the original transaction.

\section{Parties to a bill of exchange}

* Drawer: - Is the party that issues a bill of exchange (creditor) in business transaction, usually the seller;

* Drawee: - Is the recipient (debtor) of the bill of Exchange for payment or acceptance in a business transaction, usually the buyer; and

* Payee: - Is the party to whom the bill is to be paid, usually the seller or their bankers.

To the person who is to receive the money on maturity, the document is known as a Bill Receivable, while to the person is to pay the sub-due on maturity it is known as a Bill Payable. This unconditional order to pay a determinate sum of money should contain the name of the person who is to pay; a statement of the time of payment; a statement of the place where payment is to be made; the name of the persons to whom or to whose order payment is to be made; a statement of the date and of the place where the bill is issued; and the signature of the person who issues the bill.

\section{Dishonoured Bills}

A bill is said to be dishonoured when the debtor (drawee) fails to make payment on maturity. When this happens, the holder of the bill will have recourse against the person who had negotiated the bill to him. This person will also have recourse against the person that negotiated the bill to him until the final recourse is had against the drawer of the bill for the amount of money of the bill for the amount on money due on the bill. The drawer's right of action is then against the acceptor.

When a bill is dishonoured, it is noted by handling it to a lawyer who now acts in his capacity as a notary public. The notary public then represents the bill to the acceptor and collects a fee known as the noting charge. When it involves a foreign bill, the bill is also protested. Negotiation is another step that can be taken where the drawer agrees with the acceptor to draw another bill. Legal action should be the last option.

It should be noted that the amount of the expense of noting and protest be borne by the acceptor while the discounting charge is borne by the drawer or holder of the bill who has decided to discount the bill. A bill is said to be retired when it is being paid off before maturity. A rebate is often allowed on this. If a fresh bill is drawn and the term of credit is being extended, then it will include an interest.

\section{Function of Bills of Exchange}

The bill of exchange performs many functions which include the followings:

a. It facilitates the granting of trade credit in a legal format by permitting payments on agreed future dates;

b. It provides formal evidence of the demand for payment from a seller to a buyer;

c. It provides the seller with access to finance by permitting them to transfer debts to a bank or other financier by merely endorsing the bill of exchange for that bank or financier;

d. Permits the banker or financier to retain a valid legal claim on both the buyer and the seller. In certain circumstances a bank or financier many have a stronger legal claim under a bill than the party that sold them the debt;

e. It permits a seller to obtain a greater security over the payment by enabling a bank to guarantee a drawee's acceptance (guarantee to pay on the due date) by signing or endorsing the bill; and

f. Allows a seller protect their access to the legal system in the event of problems, while providing easier access to that legal system.

Difference between bill of exchange and Promissory Note

A bill of exchange differs from a Promissory Note on the following points

Table 1: Difference between a Promissory Note and a Bill of Exchange

\begin{tabular}{|l|l|l|}
\hline & Promissory Note & Bill of Exchange \\
\hline 1 & It is a promise to pay & It is an order to pay \\
\hline 2 & There are only two parties, the drawer and the payee & There are three parties, the drawer, the drawee and the payee \\
\hline 3 & There is no necessity of acceptance & It must be accepted \\
\hline 4 & The maker is primarily liable & The drawer is not primarily liable \\
\hline 5 & It is never drawn in sets & Foreign bills are specially drawn in sets \\
\hline 6 & Protesting is not necessary after dishonor & A foreign bill must be protested upon dishonour \\
\hline
\end{tabular}

Source: Accounting for Management (2011)

\section{Advantages of bill of exchange}

1. It is a legal evidence of debt

2. It is a convenient method for the transfer of debt

3. A creditor can sue on the bill itself

4. It is a negotiable instrument and can be transferred for settlement of one's debt without difficulty 
5. It can be cashed before due date by discounting

6. A debtor enjoys the benefit of full period of credit

7. It affords an ease means of transmitting money from one place to another

It is for the aforesaid advantage, a buyer can easily be included to purchase goods and accept bills drawn on him by the seller when he is not prepared to pay cash at the time of purchase. The ledger entries are given below to show how the records are made, both in the drawer's book and the drawee's book.

\section{Ledger Entries}

In the drawer's books:

a. If the bill is held by the drawer until maturity when the drawee makes payment.

DR drawee's account with the sales value

CR drawee's account with the amount receivable

DR Bills Receivable account with the amount

CR Bills Receivable account with cash received

b. Where the bill is negotiated to another party by the drawer, say Trio Nigeria Limited on $3^{\text {rd }}$ Jan., 2013

DR drawee's account with sales value

CR drawee's account with amount receivable

DR bills Receivable account with the amount

CR Bills Receivable account with the amount negotiated with the third party

c. If the bill is discounted with the bank, let's say on $3^{\text {rd }}$ January, with a discounting charge of N12,000

DR Drawee's account with the sales value

CR Drawee's account with the amount received

DR Bills Receivable account with the value

CR Bills Receivable account with the cash received

DR Bank account with the cash received

CR Bank account with the discounting charges

The ability to negotiate or discount bill of exchange can be extremely important source of finance in trade. The bill of exchange can provide easier access to financing because it enables the financing bank to retain a claim on all parties to the bill. In addition, parties that finance bill of exchange can in certain circumstance obtain stronger rights than the party transferring the bill to them. Bill discounting may provide access to finance rates lower than the old or loan rate the seller could normally obtain.

\section{Methodology}

The population comprises of all market women in Ijebu-North Local Government Area of Ogun State in Nigeria. A sample of one hundred (100) market women was drawn from the population using a simple random sampling technique. The size was generated by selecting 20 respondents from 5 markets in the local government area. This consists of provision distributors, household or kitchen utensils distributors, foodstuff (rice, beans, flour) distributors, vegetable oil distributors and cloth (wares) sellers and drinks sellers who sell in bulk to retailers. These were selected because they buy in bulk from the producers and sell in smaller quantities to the retailers, who will now sell to the final consumers. They were also targeted because they are expected to make use of the instrument and take the advantage of bills of exchange as a source of finance and mode of payment to their suppliers.

Owing to the nature of this work, only primary source of data was used in eliciting information from these market women through interview. Descriptive statistics was used in analyzing the data collected.

\section{Findings}

The following tables are used to present the data collected.

Table 2 Frequency Distribution of Respondents based on Markets

\begin{tabular}{|l|c|c|}
\hline Name of Market & Sample size & Percentage (\%) \\
\hline Obada (Station) & 20 & 20 \\
\hline Atikori & 20 & 20 \\
\hline Ago-Iwoye & 20 & 20 \\
\hline Mamu & 20 & 20 \\
\hline Depolu & 20 & 20 \\
\hline Total & 100 & 100 \\
\hline
\end{tabular}

Source: Research Survey 2013

Table 2 above provides information about the number of respondents sampled in each of the selected markets. An equal number of respondents were randomly sampled in each market. This was done to avoid the 
likelihood of placing emphasis on a market to the detriment of other markets since the sample size was placed at 100 .

Table 3 Characteristics of Sampled Market Women

\begin{tabular}{|l|l|l|l|c|c|c|c|}
\hline $\begin{array}{l}\text { Name of } \\
\text { Market }\end{array}$ & $\begin{array}{l}\text { Sample } \\
\text { size }\end{array}$ & $\begin{array}{l}\text { Provision } \\
\text { Sellers }\end{array}$ & $\begin{array}{l}\text { Household utensils } \\
\text { Sellers }\end{array}$ & $\begin{array}{l}\text { Foodstuff } \\
\text { Sellers }\end{array}$ & $\begin{array}{l}\text { Vegetable } \\
\text { oil sellers }\end{array}$ & $\begin{array}{l}\text { Wares } \\
\text { Sellers }\end{array}$ & $\begin{array}{l}\text { Drinks } \\
\text { Sellers }\end{array}$ \\
\hline Obada & 20 & 4 & 3 & 4 & 3 & 3 \\
\hline Atikori & 20 & 3 & 3 & 5 & 3 & 3 \\
\hline Ago-Iwoye & 20 & 3 & 3 & 6 & 3 & 3 \\
\hline Mamu & 20 & 3 & 2 & 6 & 3 & 3 & 3 \\
\hline Depolu & 20 & 2 & 3 & 26 & 3 & 3 \\
\hline Total & 100 & 15 & 14 & & 3 & 3 \\
\hline
\end{tabular}

Source: Research Survey 2013

Table 3 above showed the categories of the market women who are supposed to be using the bill of exchange as a means of exchange for their transactions. 15 respondents representing $15 \%$ are provision distributors, 14 respondents representing 14\% are household sellers, 26 respondents representing $26 \%$ are foodstuff sellers, 15 respondents representing $15 \%$ are vegetable oil sellers, and 15 respondents representing $15 \%$ are wares sellers, while 15 respondents representing $15 \%$ are drinks sellers.

Table 4 Use of bill of exchange among Sampled Market Women

\begin{tabular}{|l|c|c|c|}
\hline Name of Market & Sample size & Uses bill of exchange & Don't use bill of exchange \\
\hline Obada & 20 & 4 & 16 \\
\hline Atikori & 20 & 2 & 18 \\
\hline Ago-Iwoye & 20 & 3 & 17 \\
\hline Mamu & 20 & 1 & 19 \\
\hline Depolu & 20 & - & 20 \\
\hline Total & 100 & 10 & 90 \\
\hline
\end{tabular}

Source: Research Survey 2013

Table 4 above showed that 10 respondents representing only $10 \%$ are aware and uses the bill of exchange, while a larger percentage of 90 respondents are ignorant of the advantages that can be gotten from the use of bill of exchange.

\section{Conclusions and Recommendations}

Despite all the tremendous benefits that are inherent in the use of bill of exchange by merchants (traders and or the business men and women), its use and adoption by the market women in Nigeria is still very low. Many market women in Nigeria prefer to carry out their transactions using cash. This is due to their ignorance of the benefits that can accrue to the use of this instrument. Many of this market women belief in the use of the other traditional credit facilities like the popular daily contribution, loans from the cooperative societies, sales or return and the other form of contribution known as 'esusu'. The whole world is moving towards electronic commerce whereby cash will not be used at all in all business transactions. In fact, in the developed countries, the use of electronic bill of exchange is being advocated. It is very sad to discover that most of Nigerian market women still carry a lot of physical cash about even when the government has seriously warned against carrying physical cash about by the introduction of the e-payment and the online banking. This has given room to the men of the underworld to visit them in their homes.

The government still has a long way to go. It is therefore recommended that the government (local, state and federal level) should still embark on massive creation of awareness of this type of instrument and others that will make business transactions easier for the market people. The extensive use of bills of exchange both required and encouraged the development of organized exchange markets. These organized exchange markets known as 'banking places' also have a role to play in exposing the entire society to the use of bill of exchange and the safety gotten by using it.

\section{References}

[1] Blomquist, T. W. (1990), "Some observations on early foreign exchange banking based upon new evidence from thirteenth century Lucca," Journal of European Economic History 19(2), Fall, 353-75.

[2] Igben, R.O (2009) Financial accounting Made Simple. $3^{\text {rd }}$ Ed. Vol. 1.Lagos, ROI Publishers.

[3] Kohn,M (1999) "Bills of Exchange and the Money Market to 1600”A Working Paper. Hanover, Darthmouth College 99-04

[4] Larson, K.D et al (1999) Fundamental Accounting Principles. Boston. McGraw Hill

[5] Wood, F. and Sangster, A. (2008). Business Accounting 1. Great Britain. Financial Times Professional Limited.

[6] Dictionary of Business Terms (2000). Baron's Educational Series, Inc.

[7] Britanica Concise Encyclopedia (2006) Enc. Brit.Inc.

[8] http://www.duhaime.org/LegalDictionary/Billof Exchange.aspx. 